\title{
KONSEP ACTIVE-PARTICIPANTS-CYBER-LEARNING DALAM MENDONGKRAK PERAN ORIENTASI KEWIRAUSAHAAN TERHADAP KINERJA : SEBUAH PERSPEKTIF ORGNAISASI PEMBELAJAR
}

\author{
Iwan Hermawan $^{1,}{ }^{\varpi)}$, I. Inayah ${ }^{2)}$, S. Sartono ${ }^{3)}$, S Suharnomo ${ }^{4)}$ Ivana Rizki \\ Aulia ${ }^{5)}$ \\ ${ }^{1}$ Fakultas Ekonomika dan Bisnis, Universitas Diponegoro, Jl. Prof Soedarto, Tembalang, Semarang \\ ${ }^{2,5}$ Administrasi Bisnis, Politeknik Negeri Semarang, Jl. Prof Soedarto, Tembalang, Semarang \\ ${ }^{3}$ Akuntansi, Politeknik Negeri Semarang, Jl. Prof Soedarto, Tembalang, Semarang \\ ${ }^{4}$ Fakultas Ekonomika dan Bisnis, Universitas Diponegoro, Jl. Prof Soedarto, Tembalang, Semarang \\ ${ }^{\Xi}$ Email: ${ }^{1}$ iwanpolines@gmail.com
}

\begin{abstract}
This study refers to the problem in the form of a research gap between the influence of entrepreneurial orientation on organizational performance that is still inconclusive, open empty space in developing a middle concept that is able to mediate its second role so that it becomes a leverage on organizational performance. The direction of this research is to examine the concept of Active Participant Cyber Learning (APCL) in its capacity to gain pareto market access, both concepts in its elaboration will be able to bridge this gap problem. The research sample was at the organizational level collected from 172 UKM convection owners. The results showed that there was a significant effect of entrepreneurial orientation on the organizational performance $(\beta=5,851, C R \quad 0.77,0.44)$, resulted that there was a significant of entrepreneurial orientation on the active participant cyber learning ( $\beta=1.080, C R$ 5.72, sig $<0.001)$, there was a significant effect of active participant cyber learning on the performance $(\beta=-$ 0.64, CR -2.09, sig<0.001), so it revealed that concept of APCL can be a full mediator that drive the significant influence of entrepreneurial orientation on the organizational performance.
\end{abstract}

Keywords : Cyber Learning, Entrepreneurship Orientation, Organizational Performance, Industry 4.0.

\begin{abstract}
ABSTRAK
Penelitian ini merujuk permasalahan berupa gap penelitian antara pengaruh orientasi kewirausaan terhadap kinerja organisasi yang masih inkonklusif, sehinga terbuka ruang kosong dalam mengembangkan konsep tengah yang mampu memediasi peran keduannya sehingga mampu mendorong pada kinerja. Arah penelitian ini adalah menguji konsep Active Participan Cyber Learning (APCL) mendapatkan akses pasar pareto, kedua konsep dalam elaborasinya akan mampu ini menjembatani gap permasalahan. Sampel penelitian ini berada pada level organisasi yang dikumpulkan dari 172 owner UKM konveksi. Hasil penelitian ditemukan adanya pengaruh tidak signifikan antara orientasi kewirausahaan terhadap kinerja organisasi $(\beta=5,851, C R 0.77,0.44)$, dihasilkan adanya pengaruh signifikan antara orientasi kewirusahaan terhadap active partisipan cyber learning $(\beta=1.080$, CR 5.72, sig<0.001), adanya pengaruh signifikan antara active partisipan cyber learning terhadap kinerja $(\beta=-0.64, C R-2.09$, sig<0.001). sehingga dibuktikan konsep APCL mampu menjadi full mediator yang mendorong signifikansi pengaruh orientasi kewirusahaan terhadap kinerja organisasi.
\end{abstract}

Kata Kunci : Cyber Learning, Orientasi Kewirusahaan, Kinerja Organisasi, Industri 4.0.

\section{PENDAHULUAN}

Studi terkait pengaruh Entrepreneurial Orientation (EO) terhadap Organizational Performance (OP) merupakan studi yang menarik dan telah diteliti oleh banyak ilmuwan (David,
Jon, John, \& Amir, 2002; Morgan , Anokhin , \& Wincent, 2016; Olimpia, 2015; Oly Ndubisi \& Iftikhar, 2012; Valter, Alain, Damiano, Francesca, \& Mariangela, 2017), mulai dari pendekatan meta-analisis, empiris, konseptual atau sastra ulasan. Dimana 
EO menjadi aset penting bagi organisasi dan konstruk penting yang berupa kristalisasi proses-proses kewirausahaan yang berakar pada lima dimensi antara lain otonomi, inovasi, pengambilan risiko, proaktif dan agresifitas kompetitif (Colton et al., 2010; Lumpkin, Tom, Dess, G, \& Review, 1996; Poon et al., 2016). Lebih lanjut dalam konteks kewirusahan kreatif, Hermawan and Tripriyo (2014) dalam studinya pada wirausaha kreatif di Kota Denpasar, Jogjakarta dan Surakarta merumuskan konsep kewirausahaan dalam paradigma ekonomi kreatif dengan tiga dimensi inti: (a) manajemen internal-resiko, (b) dimensi antiplagiasi desain dan (c) daya beda unik atas produk, yang mana proses produk merujuk pada pendekatan dan hasil yang mengakomodasi keinovasian.

Inovasi diterapkan merupakan kegiatan dua tahap, dimana kreativitas ekonomi mendahului implementasi inovasi, konsep ini diperlukan bagi wirausaha untuk menunjang kinerja. Dalam sebuah organisasi wirausaha terdapat interaksi diantara unsur-unsur yang berada di dalamnya, disini terdapat peluang untuk menerapkan konsep organizational learning (OL), dalam implemtasinya dijumpai OL yang lebih open dalam relasinya, konsep ini dinamakan open innovation, pertama kali dikembangkan Henry Chesbrough (Hermawan, Sartono, Nunung, \& Luqman, 2016), inovasi yang memugkinkan arus pengetahuan eksternal berelaborasi dengan aset internal organisasi. Konsep organisasi belajar dari pelanggan, distributor, pemasok, mitra aliansi, unversitas dan lainnya diberkuat dalam studi (Levitt, Barbara, March, G, \& sociology, 1988; Sinkula, M, \& marketing, 1994; Slater, F, Narver, C, \& marketing, 1995). Indonesia merupakan negara dengan pertumbuhan ekonomi sebesar 5,17\% (2019), dengan ekspor terbesar kedua adalah fesyen.
Pemanfaatan teknologi digital untuk ekonomi menjadi salah satu alternatif yang dapat diterapkan yaitu dengan mendorong pertumbuhan pelaku usaha startup. Tahun 2018 terdapat sebanyak 992 startup di seluruh Indonesia yang telah terverifikasi. Kebanyakan startup di Indonesia bergerak di bidang $e$ commerce (35,48\%), sisanya pada bidang yang mencakup IoT (53,63\%). Hal ini sejalan dengan banyaknya pengguna internet di Indonesia pada tahun 2018 yaitu sebesar 171,2 juta jiwa (Kusnandar, 2019) dimana tren belanja dari masyarakat saat ini adalah melalui situs belanja online, dan dampaknya mengakibatkan banyak department store dan ritel-ritel besar di Indonesia yang kolaps (Lazuardi, 2017). Hal tersebut menyebabkan perubahan paradigma yang keduanya menunjukkan dinamika dan daya tarik sektor fesyen. Kajalo et al. (2015) dalam studinya mengemukkan bahawa OE membuktikan pengaruhnya signifikan terhadap OP, yang dikuatkan dalam studi (Abebe, Michael, business, \& development, 2014; Dada, Olufunmilola, Watson, Anna, \& Marketing, 2013; Smart, T, Conant, S, \& research, 1994; Yusuf, Attahir, commerce, \& management, 2002). Hal yang kontradiktif dalam studi Alegre and Chiva (2013), ditemukan bahwa OE tidak berpengaruh secara langsung terhadap OP, insignifikansi ini dikonfimasi oleh beberapa peneliti (Abdullah Kaid \& Al-Swidi, 2012; Rauch et al., 2009). Sehingga ada dua kutub pendapat dalam konsep pengaruh antara OE terhadap OP. Hal ini menyisakan ruang terbuka. Konsep ACPL diharapkan mampu menjembatani inkonkluisf gap penelitian. 
Riset Model Dan Hipotesis

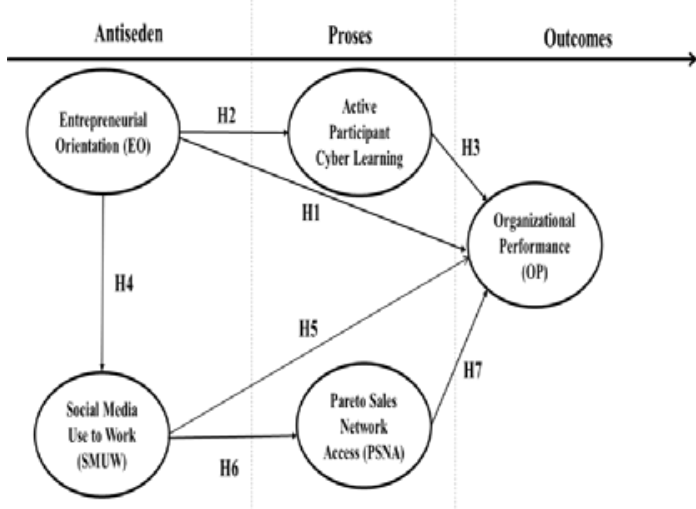

Gambar 1 Model Konseptual

Ada Pengaruh Signifikan antara OE dengan Sosial Media Use to Work (SMUW)

Menurut Stam and Elfring (2008), entrepreneurial orientation memberikan dukungan empiris terhadap konfigurasi media sosial. Hal ini perlu digarisbawahi oleh para pelaku industri sebagai modal sosial dalam mencapai kinerja organisasi yang maksimal. Sama halnya dengan $\mathrm{Wu}$, Chang, and Chen (2008), karakteristik wirausaha dalam mengambil risiko, proaktif dan inovatif sebagai dasar pengembangan modal sosial guna meningkatkan inovasi. Modal sosial ini dapat diwujudkan dalam bentuk penggunaan sosial media sebagai jembatan untuk melakukan riset pasar. Perkembangan sosial media yang bergerak secara dinamis memberikan peluang untuk mendapatkan informasi terkait short-term competitive advantage

\section{H1 : Ada Pengaruh Signifikan antara OE terhadap SMUW}

Ada Pengaruh Signifikan antara

SMUW dengan Ability to Pareto Sales

Network Access (PSNA)

Internet memiliki pengaruh positif terhadap kemampuan pasar dalam menyediakan informasi yang berdampak pada pengembangan hubungan jaringan bisnis (Bianchi, Constanza, Mathews, Shane, \& Research, 2016), dimana secara khusus sosial media dapat ekspolrasi sebagai market sensing secara akurat. Dalam memprediksi pasar biasanya organisasi berfokus pada informasi viral yang didapatkan dengan tepat waktu. Selain itu sosial media juga dapat digunakan untuk mengumpulkan informasi dalam jaringan (Chen et al., 2014). Pengunaan sosial media dimana organisasi masuk sebagai jaringan pareto, telah diteliti sebelumnya. (Brynjolfsson, $\mathrm{Hu}, \quad \&$ Simester, 2011) Sebuah teori jaringan menyatakan bahwa jaringan. Sehingga hipotesis yang kami ajukan adalah:

\section{H2 : Ada Pengaruh Signifikan antara SMUW terhadap AAPM}

Ada Pengaruh Signifikan antara OE dengan Active Participation Cyber Lerning (APCL)

OE menjadi bagian dari kemampuan organisasi yang salah satunya berupa pembelajaran aktif secara online yang berdampak terhadap kinerja organisasi. Pemanfaatan kewiraushaan yang dielaborasi infrastuktur internet dinamakan cyberentrepeneurship, konsep ini menekankan pada partisipasi aktif dan adanya trus dalam jaringan (Bouwman \& Hulsink, 2002). Chiu et al. (2006) dalam studinya menyatakan bahwa dari segi sosial, ikatan interaksi sosial, kepercayaan, norma timbal balik, identifikasi, visi bersama dan bahasa bersama, akan mempengaruhi berbagi pengetahuan dalam komunitas virtual. Sehingga hipotesis yang kami ajukan adalah :

\section{H3 : Ada Pengaruh Signifikan antara OE terhadap APCL}

Ada Pengaruh Signifikan antara APCL dengan OP

APCL merupakan fasilitas yang digunakan agar diperoleh informasi guna meningkatkan performa organisasi dengan membagikannya dalam suatu komunitas kelompok belajar secara online (Jung, Choi, Lim, \& Leem, 2002). Pembelajaran secara online 
diharapkan para pelaku industri saling bertukar informasi diberbagai platform social media khusunya dalam berbagi pengetahuan tacit (Garcia-Morales et al., 2018; Lee \& Suh, 2003). Pengaruh positif antara mobile learning terhadap performa organisasi telah diteliti oleh (Hwang et al., 2011).

\section{H4 : Ada Pengaruh Signifikan antara APCL terhadap OP}

\section{Ada Pengaruh signifikan PSNA dengan $O P$. \\ Perusahaan yang memiliki kemampuan dalam mengakses pareto sales network akan meningkatkan kekuatan jaringan pasar dimana hal ini sebagai kunci dalam mengakses rantai distribusi pada marketplace, yang dengan sendirinya akan mendongkrak kinerja perusahaan dan mempertahankan diri dari goncangan kompetitor (Ferdinan et al, 2018). Sejalan dengan Deutscher (2016), dimana perusahaan yang berorientasi pada pasar akan lebih mudah dalam meramalkan permintaan pasar. Diperlukan kolaborasi eksternal dalam rangka memperluas pasar pareto untuk meningkatkan market performance (Wang, Dou, Zhu, \& Zhou, 2015).}

\section{H5 : Ada Pengaruh Signifikan antara AAPM terhadap OP}

Ada Hubungan Signifikan antara

SMUW dengan OP

Berlawanan dengan harapan, ikatan dan kepercayaan, jaringan organisasi melalui sosial media tidak memiliki hubungan yang signifikan dengan kinerja kerja organisasi (Cao et al., 2016). Tidak adanya standar pengukuran untuk penggunaan media social yang berpengaruh terhadap kinerja suatu organisasi menyebabkan musatahil bagi organisasi untuk membuktikan bahwa investasi dalam teknologi media sosial telah menghasilkan untung atau rugi secara langsung. Ada keterkaitan antara SMUW degan kinerja disampikan (Jue, Marr, \& Kassotakis, 2009). Pengukuran sangat subjektif dan sering ditafsirkan secara unik oleh entitas yang melakukan pengukuran (Ahmad et al., 2019).

\section{H6: Ada Pengaruh Tidak Signifikan antara SMUW terhadap OP}

Ada Pengaruh Signifikan antara $O E$ dengan $O P$.

Pengaruh OE terhadap OP merupakan gap penelitian dalam paper ini, penelitian Alegre and Chiva (2013) membuktikan adanya pengaruh tidak signifikan antara entrepreneurial orientation terhadap organizational performance, sehingga dikembangkan dalam paper ini kebaruan konsep yang mampu mendongkrak pengaruh entrepreneurial orientation terhadap organizational performance.

\section{H7: Ada Pengaruh Signifikan antara OE terhadap OP}

\section{METODE PENELITIAN}

\section{Sampel}

Penelitian ini menggunakan teknik pengambilan sampel dengan metode pengambilan sampel acak sederhana (simple random sampling method). Sampel adalah pemilik / top manajer (Lyles, A, Schwenk, R, \& studies, 1992) UKM konveksi, responden tersebar di beberapa wilayah Provinsi Jawa Tengah (Pati, Demak, Kudus, Jepara dan Gabus) dan Yogyakarta. Selain itu, pengisian kuesioner menggunakan non self-assessment, dimana tim surveyor memandu pengisian kuesioner yang dilakukan oleh para responden. Sistem ini akan memudahkan surveyor dalam validasi dan konfirmasi jawaban. Profil responden penelitian ini meliputi berbagai umur usaha yang beragam, dengan rentang umur usaha kurang dari 10 tahun sampai dengan lebih dari 31 tahun. Usaha dengan umur usaha 
kurang dari 10 tahun sejumlah 91, 11 sampai dengan 20 tahun sejumlah 48 , 21-30 tahun sejumlah 14 dan lebih dari 31 tahun sejumlah 19. Selain itu juga ada 2 jenis usaha yang masing-masing berjumlah 12 usaha warisan dan 160 usaha rintisan sendiri. Didata pula jumlah karyawan, dengan jumlah karyawan kurang dari 10 orang sejumlah $120,11-21$ orang sejumlah 28 , 22-32 orang sejumlah 18 dan lebih dari 33 orang sejumlah 6 orang. Kemudian ada data mengenai modal usaha dengan rentang 1.000.000-5.000.000 sejumlah 58, 5.000.000-10.000.000 sejumlah 18, 10.000.000-15.000.000 sejumlah 10 , lebih dari 15.000.000 sejumlah 50 dan sisanya sebanyak 36 tanpa modal. Selanjutnya data mengenai asal modal usaha terdiri dari dua jenis, modal sendiri/tabungan sejumlah 121, pinjaman sejumlah 23 dan modal lainnya sejumlah 28. Data berikutnya mengenai omset penjualan/bulan, $<1.000 .000$ sejumlah $11,1.000 .000-$ 5.000 .000 sejumlah $77, \quad 5.000 .000-$ $10.000 .000 \quad$ sejumlah 26,10.000.00015.000.000 sejumlah 16 dan sisanya $>15.000 .000$ sejumlah 42 . Data mengenai biaya produksi juga ditampilkan dengan rentang $<10 \%$ 30\%/bulan sejumlah 14, 31\%61\%/bulan sejumlah 98, 62\%-92\% sejumlah 56, dan $>93 \%$ sejumlah 4 . Data terakhir mengenai cabang usaha dengan 3 jenis antara lain usaha dengan 1-2 cabang sejumlah 56, >3 cabang sejumlah 2 dan sisanya sejumlah 114 usaha tidak memiliki cabang.

\section{Pengukuran (Measurement)}

Pengujian dilakukan terhadap lima variabel yang terdiri dari Entrepreneurial Orientation (EO) yang memiliki dimensi sebagai berikut: proaktif, agresifitas, berani mengambil risiko, dan inovatif (Hermawan \& Tripriyo, 2014). Active Participant Cyber Learning (APCL) dengan dimensi diantaranya kepercayaan, tanggapan orang lain, berbagi informasi rahasia, keinginan mendapatkan informasi, dan keinginan memberikan informasi (Real, Leal, \& Roldán, 2006). Social Media Use to Work (SMUW) dengan dimensi diantaranya informasi turunan, diseminasi informasi, dan responsif (Trainor, Andzulis, Rapp, \& Agnihotri, 2014). Pareto Sales Network Access (PSNA) dengan dimensi sebagai berikut: jaringan pasar luas, intelligence dissemination, dan intelligence generation (Jaworski \& Kohli, 1993). Organizational Performance (OP) terdiri dari tiga dimensi diantaranya inovasi, kreatifitas, dan ide baru (Gumusluoglu \& Ilsev, 2009). Confirmatory Factor Analysis dilakukan guna memastikan kelayakan data sebelum dilakukan analisis lanjutan. Selanjutnya, analisis data mengunakan metode structural equation modelling (SEM) dengan aplikasi AMOS. Model menunjukkan normalitas data pada skew rentang 0.332 hingga 0.024 dan CR rentang 1,777 hingga 0.128. Uji CFA dari masing-masing variable menghasilkan data sebagai berikut:

\begin{tabular}{cccc}
\multicolumn{2}{c}{ Tabel 2. Loading Faktor Variable } & \\
Variable & Indikator & Loading Faktor & CR \\
& & & \\
EO & EOCA & 0.73 & 0.50 \\
& EORTK & 0.57 & \\
\multirow{4}{*}{ APCL } & EOFIN & 0.66 & \\
& CLFF1 & 0.73 & 0.56 \\
& CLFF2 & 0.80 & \\
& OTRS & 0.50 &
\end{tabular}




\begin{tabular}{cccc} 
OP & CRE3 & 0.53 & 0.56 \\
& CRE4 & 0.76 & \\
\multirow{2}{*}{ PSNA } & CRE5 & 0.75 & \\
& ASP2 & 0.66 & 0.59 \\
& ASP3 & 0.86 & \\
\hline Variable & Indikator & Loading Faktor & CR \\
\hline \multirow{2}{*}{ SMUW } & ASP4 & 0.55 & \\
& SMU2 & 0.80 & 0.80 \\
& SMU3 & 0.86 & \\
& SMU4 & 0.78 & \\
\hline
\end{tabular}

Berdasarkan Tabel 2, diketahui semua nilai loading faktor dari masing-masing variabel diatas 0.50 . Hanya terdapat satu indicator OTRS milik variabel APCL bernilai 0.50 . Namun secara keseluruhan dapat dikatakan bahwa indikator-indikator yang digunakan mampu mewakili masing-masing variabel. Selain itu, nilai composite reliability $(\mathrm{CR}) \geq 0.5$ sehingga dapat disimpulkan bahwa data layak untuk digunakan.

Tabel 3. Summary of Confirmatory Factor Analysis

\begin{tabular}{lccccccc}
\hline Variable & Chi-Square & $\begin{array}{c}\text { CMIN/DF } \\
\mathbf{S}_{\mathbf{2 . 0 0}}\end{array}$ & $\begin{array}{c}\text { GFI } \\
\mathbf{2 0 . 9 0}\end{array}$ & $\begin{array}{c}\text { AGFI } \\
\mathbf{2 0 . 9 0}\end{array}$ & $\begin{array}{c}\text { CFI } \\
\mathbf{0 0 . 9 5}\end{array}$ & $\begin{array}{c}\text { TLI } \\
\geq \mathbf{0 . 9 5}\end{array}$ & $\begin{array}{c}\text { RMSEA } \\
\leq \mathbf{0 . 0 8}\end{array}$ \\
\hline OK & 1,867 & 0,933 & 0,995 & 0,974 & 1,000 & 1,004 & 0,000 \\
APCL & 3,101 & 3,101 & 0,991 & 0,911 & 0,986 & 0,985 & 0,111 \\
FP & 0,684 & 0,684 & 0,998 & 0,981 & 1,000 & 1,009 & 0,000 \\
AAPM & 0,090 & 0,45 & 1,000 & 0,998 & 1,000 & 1,060 & 0,000 \\
SMUW & 0,812 & 0,406 & 0,998 & 0,988 & 1,000 & 1,013 & 0,000 \\
\hline
\end{tabular}

Hasil uji CFA dari masing-masing variable menunjukan hasil yang memuaskan sehingga setiap variable terbukti fit. Hal ini mengonfirmasi keandalan konstruk dalam mempresentasikan variabel yang ada.

\section{HASIL DAN PEMBAHASAN}

Metode yang dipilih untuk menganalisis data yaitu dengan menggunakan Structural Equation Model (SEM), yang terdiri dari beberapa langkah. Langkah pertama adalah menyusun konstruk masing-masing variabel untuk mendapatkan model yang paling fit. Selanjutnya, menggabungkan masingmasing variabel dalam satu model hingga mendapatkan model terbaik. Hal yang harus diperhatikan adalah memastikan data berdistribusi normal yang ditunjukan dengan nilai CR pada Skew ada pada rentang -2.00 hingga 2.00, kemudian memastikan bahwa signifikansi pada hubungan antar variable baik yaitu dengan nilai $* * * \mathrm{p}=$ $<0.001$ dan $* * \mathrm{p}=<0,05$.

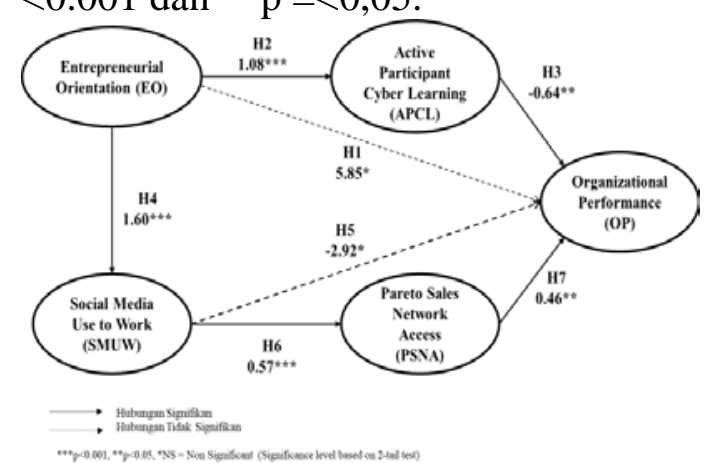

Gambar 2 Uji Kausalitas Model 
Berdasarkan uji yang dilakukan, diketahui hasil chi-square $79.761 \leq$ 88.25 dengan derajat bebas 68, Probability $0.156 \geq 0.05$, CMIN/DF $1.173 \leq 2.00$, GFI $0.944 \geq$ 0.90 , AGFI $0.902 \geq 0.90$, CFI $0.988 \geq$ 0.95 , TLI $0.982 \geq 0.95$, RMSEA 0.032 $\leq 0.08$. Terlihat bahwa model yang dibangun telah memenuhi batas minimal pengukuran yang distandarkan, sehingga model dianggap dapat mewakili konsep.

Tabel 4. Direct, Indirect dan Total Effect untuk Endogenous Variabel

$\begin{array}{cccc}\text { Effects On Endogenous Variables Direct Effects } & \begin{array}{c}\text { Indirect } \\ \text { Effect }\end{array} & \begin{array}{c}\text { Total } \\ \text { Effect }\end{array}\end{array}$

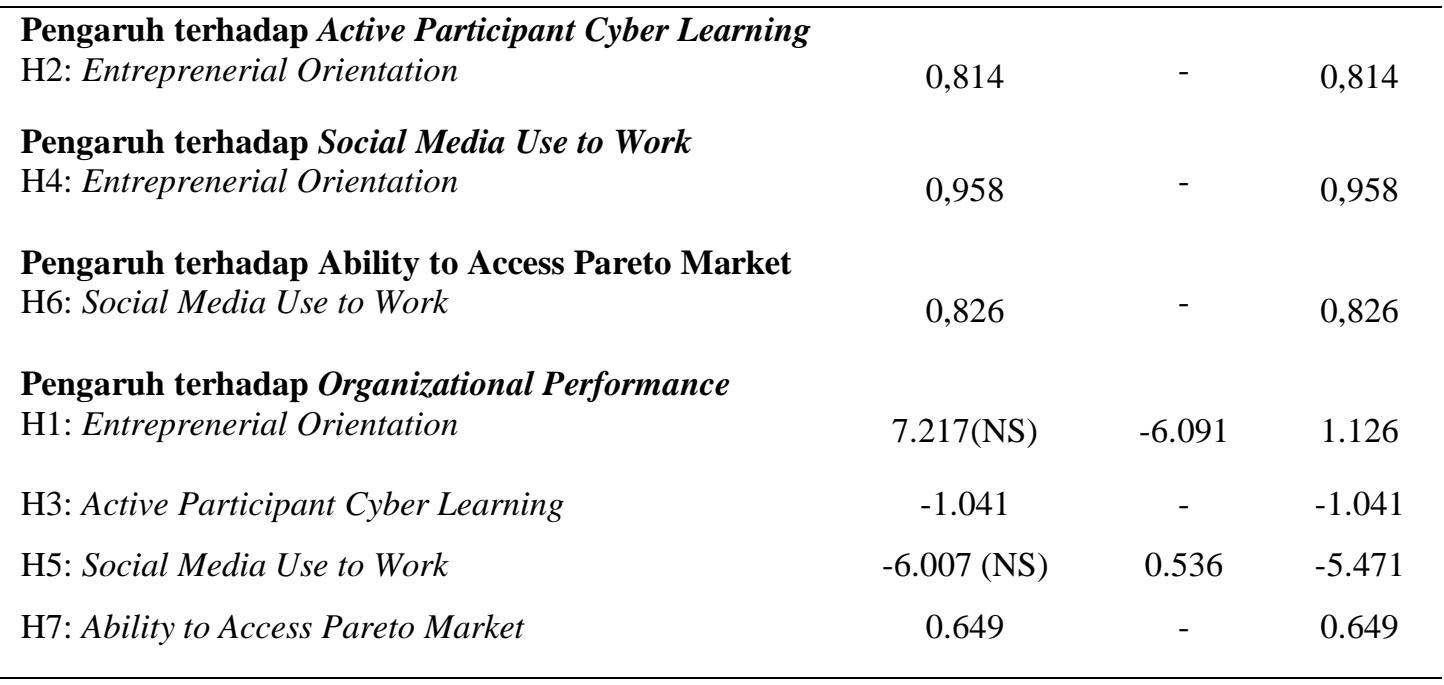

Berdasarkan uji kausalitas model yang dilakukan, terdapat lima hipotesis yang diterima yaitu H2, H3, H4, H6, dan $\mathrm{H} 7$ dan menolak H1 dan H5 sesuai dengan dasar teori yang dipaparkan sebelumnya (Alegre \& Chiva, 2013). Perhitungan total pengaruh memberikan pembuktian bahwa variabel active participant cyber learning menjadi mediator yang tepat antara entrepreneurial orientation terhadap organizational performance. APCL memberikan dorongan sebesar 0.814 terhadap entrepreneurial orientation.

\section{Pembahasan}

Analisis menyimpulkan bahwa hipotesis 1 ditolak, dimana entrepreneurial orientation tidak berpengaruh secara signifikan terhadap organizational performance. Hal ini benar adanya, karena diperlukan router untuk mengimplementasikan entrepreneurial orientation sehingga dapat meningkatkan organizational performance. Gap penelitian terpecahkan dengan diterimanya hipotesis 2 yakni terdapat pengaruh entrepreneurial orientation terhadap active participant cyber learning yang selanjutnya berpengaruh terhadap organizational performance, dibuktikan dengan diterimanya hipotesis 3. Kemauan keras dari pelaku industri untuk berinovasi dan berani mengambil risiko membuka kesempatan sebagai partisipan aktif dalam pembelajaran secara online. Pembelajaran ini penting karena mengikuti perkembangan zaman yang melek teknologi. Upaya untuk mendapatkan pengetahuan secara online yang pada dasarnya memperluas jaringan eksternal memungkinkan pelaku industri menyerap tacit knowledge dari rekan 
bisnis lainnya. Hal ini secara langsung akan berpengaruh terhadap kemampuan organisasi dalam menghadapi pasar sehingga mencapai kinerja yang maksimal. Namun, berdasarkan hubungan kausal model yang dianalisis, diketahui pengaruh active participant cyber learning berarah negatif terhadap organizational performance. Secara practical, hal ini terjadi karena tingginya nilai investasi yang diperlukan untuk menjangkau cyber learning antar pelaku bisnis yang berbanding terbalik dengan organizational performance. Hipotesis 4 diterima, dimana entrepreneurial orientation berpengaruh secara signifikan terhadap social media use to work. Karakteristik inovatif dan berani mengambil risiko dari wirausaha memudahkannya untuk memahami pergerakan pasar terutama melalui sosial media. Bukanlah hal yang sulit untuk mengikat pasar melalui promosipromosi inovatif di sosial media. Hipotesis 5 ditolak, dimana social media use to work tidak berpengaruh signifikan terhadap organizational performance. Social media sebagai wadah bagi pelaku industri untuk melihat potensi pasar, tentu dibutuhkan moderating role untuk mengolah informasi potensial yang didapatkan guna peningkatan kinerja. Oleh karena itu, penelitian ini menawarkan variabel pareto sales network access sebagai transformator pengetahuan yang didapatkan untuk memperlancar jalur distribusi perusahaan terhadap pasar sehingga didapatkan competitive advantage bagi organisasi. Hal ini dibuktikan dengan diterimanya hipotesis 6, dimana social media use to work berpengaruh secara signifikan terhadap pareto sales network access yang kemudian berpengaruh secara signifikan terhadap organizational performance sehingga hipotesis 7 diterima.

\section{KESIMPULAN DAN SARAN}

Sesuai dengan tujuan dari studi ini yakni mengeksplorasi model konseptual baru untuk menjembatani gap penelitian yang ada mengenai pengaruh entrepreneurial orientation terhadap organizational performance, dapat disimpulkan bahwa pengaruh entrepreneurial orientation dalam mengembangkan kemampuan organisasi atau organisasi mampu mengakselerasi setiap individu dalam memunculkan ide-ide kreatif guna pengembangan bisnis. Selain itu, ditemukan pula variabel novelty yakni APCL yang memfasilitasi EO untuk dapat meningkatkan OP. Penggunaan teknologi untuk memperluas jaringan sosial melalui sosial media menjadi sorotan utama saat ini. Organisasi harus bisa memanfaatkannya dengan baik untuk mendapatkan competitive advantage yang maksimal. Implikasi pembelajaran yang dapat diambil adalah konveksi jahit saat ini sebagian besar tidak berprinsip belajar secara online. Berdasarkan penelitian diatas, terbukti bahwa dengan adanya APCL akan membantu dalam memunculkan kreatifitas guna pengembangan bisnis yang berdampak terhadap kinerja organisasi.

\section{DAFTAR PUSTAKA}

[1] Abdullah Kaid, \& Al-Swidi. (2012). Total quality management, entrepreneurial orientation and organizational performance: The role of organizational culture. African Journal of Business Management, $6(13)$. doi:10.5897/ajbm11.2016

[2] Abebe, Michael, business, J. J. o. s., \& development, e. (2014). Electronic commerce adoption, entrepreneurial orientation and small-and medium-sized enterprise (SME) performance. 21(1), 100- 
116. doi:10.1108/JSBED-10-20130145

[3] Ahmad, Zamberi, S., Abu Bakar, Rahim, A., Ahmad, Norita, . . . Research. (2019). Social media adoption and its impact on firm performance: the case of the UAE. 25(1), 84-111. doi:10.1108/IJEBR08-2017-0299

[4] Alegre, J., \& Chiva, R. (2013). Linking Entrepreneurial Orientation and Firm Performance: The

[5] Role of Organizational Learning Capability and Innovation Performance. Journal of Small Business Management, 51(4), 491507. doi:10.1111/jsbm.12005

[6] Bianchi, Constanza, Mathews, Shane, \& Research, J. J. o. B. (2016). Internet marketing and export market growth in Chile. 69(2), 426-434. doi:10.1016/j.jbusres.2015.06.048

[7] Bouwman, H., \& Hulsink, W. (2002). A dynamic model of Cyber-entrepreneurship and cluster formation: applications in the United States and in the Low Countries. Telematics and Informatics, 19(4), 291-313. doi:10.1016/S07365853(01)00018-1

[8] Brynjolfsson, E., Hu, Y., \& Simester, D. (2011). Goodbye Pareto Principle, Hello Long Tail: The Effect of Search Costs on the Concentration of Product Sales. 57, 1373-1386. doi:10.1287/mnsc.1110.1371

[9] Cao, Xiongfei, Guo, Xitong, Vogel, Douglas, . . . Research, J. 
